\title{
Confucian Ethics, Governance and Corporate Social Responsibility
}

\author{
Patrick Kim Cheng Low ${ }^{1} \&$ Sik Liong Ang ${ }^{1}$ \\ ${ }^{1}$ Universiti Brunei Darussalam, Jalan Tungku Link, Gadong, Brunei \\ Correspondence: Faculty of Business, Economics and Policy Studies, Universiti Brunei Darussalam, Jalan \\ Tungku Link, Gadong BE 1410, Brunei. E-mail: angsikliong@gmail.com
}

\author{
Received: September 19, 2012 Accepted: December 24, 2012 Online Published: January xx, 2013 \\ doi:10.5539/ijbm.v8n4p30 \\ URL: http://dx.doi.org/10.5539/ijbm.v8n4p30
}

\begin{abstract}
The authors believe that the reasons for the corporate and financial institution collapses, business scams, frauds and bankruptcies and other unethical practices in the United States, Europe and other parts of the world have very much to do with leadership, governance and corporate social responsibility (CSR) (Kothari, 2010; Low, 2009; 2009a; Low and Ang, 2011; 2012; 2012a; 2012b). Whenever an organisation collapses, employees (labour) suffer; they are not protected; they are the first to go; and they face retrenchments and unemployment.

Facing with such uncertainty in the business world, the authors feel that business leaders and managers need or should seek fresh and effective ways of thinking and actions in applying business ethical principles in decision making to sustain their business performance and growth; protecting their labour or workforce in line with corporate social responsibility in a global setting.

The authors interpret and present Confucian ethics and business lessons derived from Confucius' sagely wisdom. From Confucian ethics emanate the emphasis on social obligations, ethical decision-making, positive business dealings and harmonious relationships within the organisation and the value of learning and education; these bring attendant benefits and good practices including good business management and labour practices as well as corporate social responsibility. The paper too includes a research model, research methodology and its findings, discussions as well as an analysis with its concluding remarks. The understandings and practices of Confucian ethics and social obligation in a business organization coupled with awareness and applications of corporate social responsibility can bring much peace, harmony, learning and economic growth for both the organization and the community well-being in the region.

This paper specifically aims to bring in an Asian historical perspective and insights to the field of CSR and compare them with the Western perspective. It is hoped that by engaging some of the rising leaders and managers from both Western and non-Western countries, the understanding of CSR of its terminology can be further explained, clarified and be better used a basis for developing linkages between Western and Asian thoughts.
\end{abstract}

Keywords: Confucian ethics, human resource management, social obligation, corporate social responsibility (CSR), governance

\section{Introduction}

Global greenhouse effect, terrorist attacks, corporate and financial institutions' collapse, business scams; frauds and bankruptcies, and other unethical practices in the United States, Europe and other parts of the world have very much to do with leadership, governance and social responsibility (Kothari, 2010; Low, 2009; 2009a; Low and Ang, 2011; 2012; 2012a).

In the recent headlines, Europe's largest bank by market value, Hong Kong and Shanghai Banking Corporation: HSBC, was investigated and found to be used for money laundering purposes by "drug kingpins and rogue nations". It is believed that compliance with anti-money laundering laws is crucial to the nation's effort to combat criminal activity and terrorism. This makes one wonder and ponder on the kind of leadership and governance (monitoring measures) that have been practised in the bank as well as by the governance body of the country. The Senate committee investigating money laundering claims at the bank reported that suspicious funds from countries including Mexico, Iran and Syria had passed through the bank (BBC, 2012; The Straits Times, 2012). In December 2012, the financial giant avoid the legal battle that could further savage its reputation and undermine confidence in the global banking system by agreeing to pay $\$ 1.9$ billion to settle a U.S. 
money-laundering probe. It is the biggest penalty ever imposed on a bank after facing accusations it transferred funds through the U.S. from Mexican drug cartels and on behalf of nations such as Iran that are under international sanctions (Yost et al, 2012).

The authors reason that all these happenings have demonstrated negative practices in financial institutions/enterprises in respect of Corporate Social Responsibility (CSR), and this has very much to do with leadership, governance and corporate social responsibility [Weak leadership thus lead to poor corporate governance and weak ethical practices while strong or effective leadership certainly leads to good governance and ethical practices]. What are then the implications for the labour? One can see that when the direction of the leadership is wrong as in the above money laundering case, it would impact on the morality of the labour (employees) as well as the dismissing of the labour (employees). The question that people must ask is if this is the right way to treat the labour.

Obviously, one can suggest that because of the ever changing business environment, it is important for an individual (business leader/manager/employee) in an organization to be cautious and be aware of, more so, to embrace the business code ethics and corporate social responsibility (CSR). Living in a society and in one's setting, one must realize that one has a social responsibility towards others and environment. Looking at the bigger or whole picture, one must also agree that each firm has a social responsibility which is the firm's recognition of how its business decision(s) can affect the organisation, the labour and the society.

Not much research, reflecting and writing have been done in this area in terms of Confucian ethics supplying the fundamentals through which people do, conduct business, make business decisions or even do more for labour; besides, little have been said of linking Confucian ethics (the Eastern or Asian way) to governance, corporate social responsibility and its implications for the labour which the authors feel inclined more towards Western thinking, and need much discussion as well as analytical writing.

The purpose and objectives of this paper is to relate to or interpret Confucian ethics in the light of the governance and corporate social responsibility as well as its implications for labour.

\section{Literature Review}

About Confucius (Pinyin: Kŏng Füž̌; Wade-Giles: K’ung-fu-tzu, lit. “Master Kung”, 551 BC - 479 BC), he was an esteemed Chinese thinker and social philosopher, whose teachings and philosophy have deeply influenced Chinese, Japanese, Korean and Vietnamese thought and life (Chew, 2000) and also elsewhere, even in the Western world (Yang, 1993). His ideas have, in fact, been lasting.

At the outset, it is good to point out that little have been said of fundamentally linking Confucian ethics (the Eastern or Asian way) to its implications for the labour which is a more of a Western concept or thinking, and it appears as if the latter is unrelated, let alone, not discussed in Confucianism. Low (2009b) did highlight the tying-in of Confucian ethics with the various stakeholders/ the stakeholder theory; however, here in this paper and the paper's contributions really lie in the fact that the discussion is now extended to include leadership, governance and ethics, giving a new interpretation of pro-active Confucian ethics and that values (or that the right convictions and actions in the Confucian sense) are both essential and critical for the labour as well and in contemporary times.

\subsection{The Meaning of Tao}

Tao means "the way of life". Confucius recognized and propounded that Tao is the wisdom, the ultimate purpose and enlightenment in one's life. The master said that if an individual learns the truth about the way of life in the morning, (s)he would never regret dying in the same evening (Analects of Confucius, Chapter IX: 8 “朝聞 道,

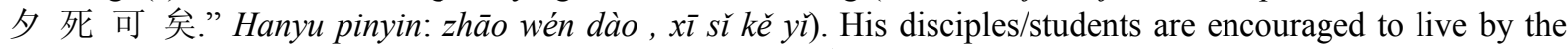
principles of setting one's aspirations on the way of life (道, dào). In this respect, an individual should embrace and practice on good virtues, values or ethics (德, dé), rely on one's (仁, rén) humaneness, and relax in the study of the arts. (Analects of Confucius, Chapter VII: 6).

Embracing and practicing Confucian ethics enables one to self-cultivate in pursuit of the Tao (Low, 2011c). It is believed that when one is close to nature, one can attain peace and harmony; and this also means that taking the right actions are more critical than just holding the belief(s). To help individuals to attain peaceful and harmonious livelihood, Confucius stressed that leaders need to be benevolent and compassionate. Therefore, Confucian business owner/leader, with its high task and high relationship, should be caring in order to build a friendly and reciprocate bond with the employees. In the Confucian sense, being benevolent or kind, a characteristic element of humanity is a part of an individual's talents (Low, 2011c, 2011d; 2008). Here, the moral dimension of Confucian ethics is applicable in attaining good leadership, good governance and social 
responsibility. Because of the fact that leaders care and concern about their subordinates/ employee (labour), they are all well taken of and look after.

\subsection{What is Ethics (德, dé)?}

Ethics is a value or a standard that a person adopts, strongly believes in, upholds, and lives by. "Ethics, the yardstick, serves as the foundational stone of doing business and it should play a critical role in every business, profit or non-profit organization, society, and nation. An individual who believes and practices ethics also means that he or she believes and practices Tao, "the way of life". Ethics is good; it pays. "Being ethical imparts a sense of trust which promotes positive alliances among business partners and associates. Confucian ethics can supply the basis through which people do, conduct business or make business decisions" (Low, 2008a: 47).

\subsection{Confucian Ethics}

Values are the core beliefs, ideas and things people care and believe most. They are people's or organization's (also read as nation's) priorities; they also provide purpose and a sense of direction; setting the standards and giving us a sense of right and wrong (Low, 2011; 2005). Some common Confucian values are: 1) Filial piety (孝, xiào); 2) brotherhood, peer-ship and equality (悌, ti); 3) loyalty and fidelity (忠, zhōng); 4) trustworthiness (信, xin); 5) courtesy and politeness (禮, lì); 6) righteousness, right conduct and courage (義, yi); 7) upright, honourable, integrity and character (廉, lien), and 8) humility and shamefulness (恥, chì). It is believed that individuals who embrace and practise Confucian ethics would carry out a proper and better livelihood; and they would establish good relationships amongst each other, and in this way more people would be encouraged to attain similar good virtues; and by continuing to do so, there would be fewer frictions in relationships and thus this creates positive energies in group dynamics and teams. All would then be working together towards a peaceful and harmonious society, and as everybody behaves in a socially responsible manner, the people (leaders/managers) in business, when relating with their employees (labour) would be able to prosper in doing their businesses. Moreover, there would be fewer problems in people relationships and in business dealings in the wider society and country (Low and Ang, 2012).

Unlike Western ethics, Confucian ethics embraced and practiced by a person is based on spirituality that is, living with and in the Tao. It also means that one becomes a person because of others; where one is never a person independently or in and of oneself but develops into one only in community (Bockover, 2010). Western ethics is strictly and explicitly individualistic concept of personhood with intrinsic characteristics not thought to depend on others (Bockover, 2010). Western ethics is, thus, based on utilitarianism, a theory in normative ethics holding that the proper course of action is the one that maximizes utility, specifically defined as maximizing happiness and reducing suffering (Mill, 1863). A person, who embraces and practices utilitarianism, ensures the greatest good for the greatest number of people.

\subsection{Social Obligation}

The authors view the term 'social obligation' can be broken down into two parts - 'social' and 'obligation'. The meaning 'social' is taken as the social entity of an organization (Meyer and Jepperson, 2000: 100). The meaning 'obligation' is taken as an organization's accountability to its stakeholders including the labour for the performance of its tasks, which are of social value (Gilbert, 2008). The authors find that the notion of social obligation is compatible with the notion of corporate governance. The theory of social obligation can provide a better and more effective corporate governance of businesses. The notion of corporate governance is largely unilateral. In other words, the leaders of an organization voluntarily choose to be socially accountable to their stakeholders (labour).

In the Confucian context, everyone is part of the One Whole World (Low, 2011c); there is a familial or collective value and pull. However, in the Western context, individualism and the rights of the individuals are upheld as paramount. Social obligation is to reduce or minimize individualism and increase individual's responsibility in an organisation (family, society and nation).

\subsection{Governance}

Conceptually, governance can be defined as the rule of the rulers, typically within a given set of rules. One might conclude that governance is the process - by which authority is conferred on rulers, by which they make the rules, and by which those rules are enforced and modified. Thus, understanding governance requires an identification of both; the rulers and the rules, as well as the various processes by which they are selected, defined, and linked together and with the society generally. Good governance in various organisations has been associated with democracy and good civil rights; with transparency; with the rule of law; and with efficient public services (The World Bank, 2011). In this respect, Confucius said that without benevolence, one would 
lose the position of power that one has attained through wisdom and talent. With benevolence, one can keep the position. However, one cannot gain the support of the multitude if one does not govern the multitude with conscience. Therefore, if one can attain a position of power with wisdom and talent, keep it with benevolence and at the same time govern the multitude with conscience, still such a regime cannot be called a perfect regime if one does not govern the multitude according to rites (Analects of Confucius, XV:33; Low 2011c). It is true that a well balanced, inclusive approach, according to certain standards, ideals (values), is imperative for the proper governance of an organization.

In Confucianism, there is a higher, superordinate order, the Tao and it stresses on personal cultivation and self-discipline and self-regulation [though over the years, it is littered with high paperwork and red-tape as exemplified during Imperial China time]. The Western concept of governance, however, stresses on individual rights with democracy that is, the right of the people to elect and select their public officials or leaders. Upon election, the leaders and his or her people decide on the governance.

\subsection{Corporate Social Responsibility (CSR)}

Different organisations have different definitions for corporate social responsibility (CSR), however, there is a considerable common ground or theme amongst them. CSR defined by the WBCSD (World Business Council for Sustainable Development) is "Corporate social responsibility is the continuing commitment by business to behave ethically and contribute to economic development while improving the quality of life of the workforce and their families as well as of the local community and society at large." (WBCSD, 2000). In 2002, the definition was further simplified to, "Corporate social responsibility is the commitment of business to contribute to sustainable economic development, working with employees, their families, the local community and society at large to improve their quality of life." (WBCSD, 2002).

In business, CSR is about how companies/organisations manage their business processes internally and externally to produce an overall positive impact on society. To be socially responsible, an organisation is expected to focus on two aspects of its operations namely: 1) the quality of its management - both in terms of people (labour) and processes (Internal workforce and machinery) 2) the nature of, and quantity of their impacts on society in the various areas (External stakeholders). Nowadays, external stakeholders are taking an increasing interest in the activity of the company. Most will look at what the company has actually done, good or bad, in terms of its products and services; how it treats and develops its workforce; and what its activities have impacted on the environment and on local communities. The financial analysts are also predominantly focused on past financial performance of the company; on quality of management as an indicator of likely future performance; and in how the company treats and develops its workforce (Baker 2004). Indeed, CSR is a form of corporate self -regulation integrated into a business model. CSR policy functions as a built-in, self-regulating mechanism whereby business monitors and ensures its active compliance with the spirit of the law, ethical standards, and international norms. The goal of CSR is to embrace responsibility for the company's actions and encourage a positive impact through its activities on society and environment (Low and Ang, 2012).

In a gist, CSR in Confucianism stresses on the compelling and natural need to return or give back to the community; thus, CSR is a natural function and part of the process or loop when doing business. On the other hand, CSR in the Western concept entails quality, benchmarking and its measurements to ensure standards and results. In the West, because of the primary need to protect individual rights, the emphasis on transparency also floats out and it becomes part of the CSR process.

\subsection{People (Labour) and Corporate Social Responsibility (CSR)}

Either an individual is at work or at home, it is important for one to treat the places one shares with respect, and with seven billion people on the planet, every place is a place he or she shares. CSR does not necessarily start from the top, it can start with anyone in the organisation who has the courage, patience and persistent to be a voice of integrity; to keep speaking and act on until others take up the good virtue or values and join one (Metcalf and Gallagher, 2012). In this respect, organisations are run by people (labour) and in fact, people are one of the important assets of the organisations (Low; 2011d). The success of an organisation depends on the quality of its people in running the business.

The element of humanism is strong in Confucianism, and by virtue of the Heavenly Mandate, the leaders are accountable to the people; and if the leaders are not responsible, then the people have the right to remove the leaders.

However, in the West CSR context, the companies may be classified as acting selfishly; they would export non-CSR practices to subcontractors in other developing countries. So they are actually keeping themselves 
clean (in line with the CSR practices) while soiling or dirtying others (other companies/ subcontractors and other countries). Take the case of a US Company using child labor in Vietnam or Indonesia to manufacture their products at lower costs.

Table 1. Differences between Confucian concept and Western concept

\begin{tabular}{|c|c|c|}
\hline Issue(s) & Confucian Concept/ Thoughts & Western Concept/ Thoughts \\
\hline Ethics & $\begin{array}{l}\text { Spirituality; living with and in the Tao; one } \\
\text { becomes a person because of others; where } \\
\text { one is never a person independently or in } \\
\text { and of oneself but develops into one only in } \\
\text { community }\end{array}$ & $\begin{array}{l}\text { Utilitarianism; one that maximizes } \\
\text { utility, specifically defined as } \\
\text { maximizing happiness and reducing } \\
\text { suffering }\end{array}$ \\
\hline Social Obligation & $\begin{array}{l}\text { Everyone is part of the One Whole World; } \\
\text { there is a familial or collective value and } \\
\text { pull. }\end{array}$ & $\begin{array}{l}\text { Individualism and the rights of the } \\
\text { individuals are upheld as paramount. }\end{array}$ \\
\hline Governance & $\begin{array}{l}\text { Govern with wisdom and talent, keep it with } \\
\text { benevolence and at the same time govern the } \\
\text { multitude with conscience and rituals. }\end{array}$ & $\begin{array}{l}\text { Based on individual rights with } \\
\text { democracy that is, the right of the } \\
\text { people to elect and select their public } \\
\text { officials or leaders. Upon election, the } \\
\text { leaders and his or her people decide } \\
\text { on the governance }\end{array}$ \\
\hline $\begin{array}{lr}\text { Corporate } & \text { Social } \\
\text { Responsibility (CSR) }\end{array}$ & $\begin{array}{l}\text { CSR in Confucianism stresses on the } \\
\text { compelling and natural need to return or } \\
\text { give back to the community; thus, CSR is a } \\
\text { natural function and part of the process or } \\
\text { loop when doing business }\end{array}$ & $\begin{array}{l}\text { CSR in the Western concept entails } \\
\text { quality, benchmarking and its } \\
\text { measurements to ensure standards and } \\
\text { results. In the West, because of the } \\
\text { primary need to protect individual } \\
\text { rights, the emphasis on transparency } \\
\text { also floats out and it becomes part of } \\
\text { the CSR process. }\end{array}$ \\
\hline $\begin{array}{l}\text { People (Labour) and } \\
\text { Corporate Social } \\
\text { Responsibility (CSR) }\end{array}$ & $\begin{array}{l}\text { The element of humanism is strong in } \\
\text { Confucianism, and by virtue of the Heavenly } \\
\text { Mandate, the leaders are accountable to the } \\
\text { people; and if the leaders are not } \\
\text { responsible, then the people have the right to } \\
\text { remove the leaders. }\end{array}$ & $\begin{array}{l}\text { Human and individual rights are } \\
\text { stressed, and hence workers' rights } \\
\text { are part and parcel of the human } \\
\text { rights spectrum. }\end{array}$ \\
\hline
\end{tabular}

\section{Research Model}

Confucian ethics is about showing care and concern for the people; and this includes employees or labour. Adopting a humanist (仁, rén) approach (Low, 2011d; 2009b), Confucian leaders/managers strive for good virtues, integrity and character; human-orientated; they are concerned with being socially responsible for their people. The following research model is developed on Confucian leaders/managers and their being caring to the people (labour) and environment (Figure 1). 


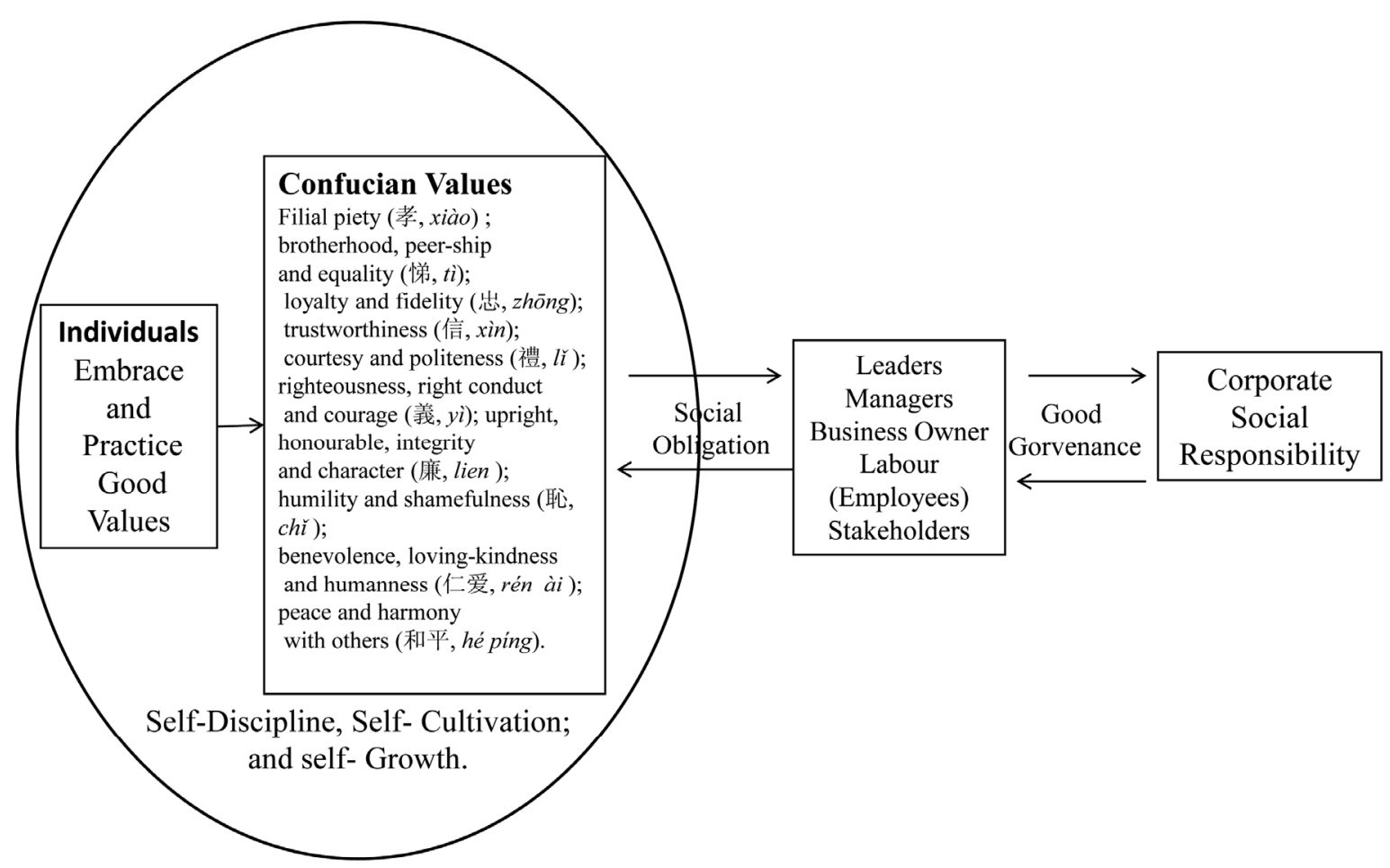

Figure 1. A research model on Confucian ethics, governance and corporate social responsibility: implication for labour

Confucian ethics can also be categorised into three sections, namely, self-development of a leader/manager, his or her relationship with others and social responsibility.

Table 2. Categorisation of Confucian values into self-development, relationships with others and social responsibility

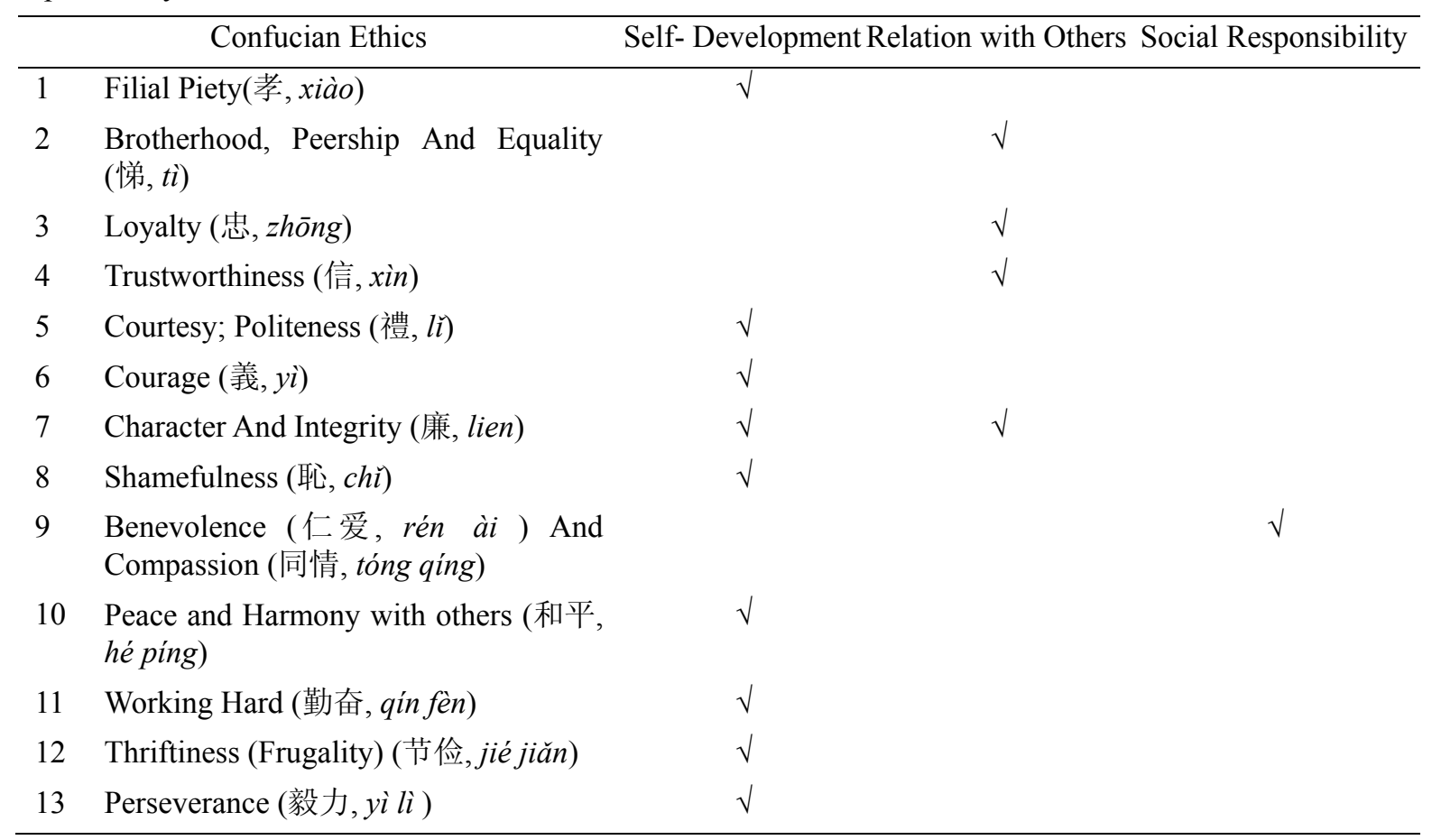




\begin{tabular}{|c|c|c|c|c|}
\hline 14 & Self-Cultivation (修养, xiū yăng) & $\sqrt{ }$ & & \\
\hline 15 & Self-Discipline (自律, Zì lì̀) & $\sqrt{ }$ & & \\
\hline 16 & $\begin{array}{l}\text { Reciprocation of greetings and favours } \\
\text { (恕, shù) }\end{array}$ & & & $\sqrt{ }$ \\
\hline 17 & Tolerance (容忍, róng rěn ) & $\sqrt{ }$ & & \\
\hline 18 & $\begin{array}{l}\text { Moderation- Following The Middle } \\
\text { Way (適度, shì dù) }\end{array}$ & & & $\sqrt{ }$ \\
\hline 19 & Prudence (Carefulness) (谨慎, ǰ̆n shèn) & $\sqrt{ }$ & & \\
\hline 20 & $\begin{array}{l}\text { Resilience (弹性, 弹力, dàn xìng, dàn } \\
\text { lì) }\end{array}$ & $\sqrt{ }$ & & \\
\hline 21 & $\begin{array}{l}\text { Continuous Learning (不斷學習, bù } \\
\text { duàn xuéxí) }\end{array}$ & $\sqrt{ }$ & & \\
\hline 22 & Being Ethical (倫理, lún ľ̌) & & & $\sqrt{ }$ \\
\hline 23 & $\begin{array}{l}\text { Honesty And Sincerity (真誠, zhēn } \\
\text { chéng; 誠實, chéng shi) }\end{array}$ & $\sqrt{ }$ & & \\
\hline 24 & Patience (忍耐, rěn nài) & $\sqrt{ }$ & & \\
\hline 25 & Impartiality (公正, gōng zhèng ) & & $\sqrt{ }$ & \\
\hline 26 & $\begin{array}{l}\text { Contributing To Society; Social } \\
\text { Obligation and responsibility (社會的 } \\
\text { 義務和責任, shè huì de yì wù hé zé } \\
\text { rèn ) }\end{array}$ & & & $\sqrt{ }$ \\
\hline 27 & Self-Awareness (自知) & $\sqrt{ }$ & & \\
\hline
\end{tabular}

In sum, the research model focuses on self-discipline, self-cultivation and hence self-development of an individual (whether from the frontline or just an employee) to become a good leader/manager/employee who in turn creates a great impact on the business in relation to good governance and corporate social responsibility.

\section{Research Methodology}

The research was conducted with a total of ninety and two (92) Chinese employers and employees who adopted the Confucian ethics, from Small and Medium Enterprises in Brunei. The period of study was from 1 September 2011 to 15 June 2011 (about nine month study). According to business researchers, sample sizes larger than 30 and smaller than 500 are appropriate for most business research. Qualitative studies typically use small sample sizes because of the intensive nature of such studies (Cavana et al, 2001: 279; Sekaran, 2000: 296 - 7 and Roscoe, 1975). The sample size of ninety-two (92) was decided because of various aspects including costs, time accessibility and limited personal resources. The critical rationale behind choosing Chinese Bruneians as the key sample for this research is primarily because many studies have shown that Overseas Chinese including Chinese Bruneians are motivated and influenced by Confucian ethics (de Bary et al, 1960; Lien and Kraar, 1994:57; Low, 2009, 2006, 2002; Low and Ang, 2011; Ang and Low, 2012), and hence the respondents' insights can be tapped to cast useful light on Confucian ethics and governance as well as corporate social responsibility.

The study focuses on the qualitative research method and it is based on face to face interviews for research data - each interview was approximately 45 minutes though some interviews stretched to more than an hour but normally less than an hour and a half. It is worthy to note that similar to Low's $(2006,2006 \mathrm{a})$ and Low and Ang's (2011b) studies, being assured of confidentiality and anonymity, the interviewees expressed themselves freely. At the beginning of these interviews, the researchers started with some small talk to put the interviewees at ease. Often, a light conversation on their personal likes and interests, detected in previous interactions or previous telephone calls, would serve as a springboard for further discussions wrong purpose and query on the motivational sources of the interviewees. This interview method is helpful since it enables much qualitative data to be collected from the interviewees. To get more data from the various interviewees, open questions were deployed (Cavana, Delahaye and Sekaran, 2001); they were crafted as:

1) What are your views on being an employer (leader/manager), the Confucian way? 
2) How does Confucian employer (leader/manager) practice good governance?

3) What can Confucian leaders/managers do to be socially responsible for their employees (labour)?

4) How do you think that embracing and practising Confucian values help you to lead well in your line of business as well as being socially responsible for your employees (labour)?

5) How do you act in a socially responsible way when doing your business?

6) How do you care about the well being (safety/health) of your employees when giving them the tasks to work on?

7) What are the ways in which you are motivated by a leader/manager who is concerned with Confucian values and to be socially responsible for your employees?

8) What do you like about being an employer (leader/manager) in the eyes of the employees, the Confucian 'style'?

9) What do you like about your employer who practise Confucian values?

10) What attracts you to such a benevolent employer (leader/manager)?

\section{Findings}

The remarks and statements made by each respondent was captured and recorded immediately during the interview so as to avoid or minimize memory lapse and data loss. After each interview, the authors clarified with the interviewees those statements which were not clear and needed further explanation. In this respect, there were many occasions that repetitive interviews were carried out for one interviewee at different day, time and venue (Plate, 2011; 2010). This is the way the authors established the verification and the validity of the statements/remarks made by the interviewees. The following is the respondents' remarks which have been sorted and categorised into several headings. (Table 3 )

Table 3. The interviewees' responses on Confucian ethics, governance and corporate social responsibility: implications for labour

\begin{tabular}{lcc}
\hline \multicolumn{1}{c}{ Responses } & $\begin{array}{c}\text { Number of } \\
\text { Interviewees }\end{array}$ & $\begin{array}{c}\text { Percentage (\%) of } \\
\text { Interviewees }\end{array}$ \\
\hline $\begin{array}{l}\text { Learning and continuous learning are both important values for } \\
\text { the self-development of individuals and their organisations }\end{array}$ & 90 & 97.8 \\
$\begin{array}{l}\text { Individuals should self -discipline and self-cultivate themselves; } \\
\text { and practise good values so that the organisation has good } \\
\text { teamwork and team spirit }\end{array}$ & 88 & 95.7 \\
$\begin{array}{l}\text { Leaders are the fountainheads and must set examples } \\
\text { Leaders embrace and practice values and these values influence } \\
\text { their corporate cultures. }\end{array}$ & 86 & 93.5 \\
Ethics are part and parcel of Confucian values & 85 & 92.4 \\
Leaders have high integrity (no self- interest or personal gain) & 83 & 92.4 \\
Leaders encourage team spirit and care about the society at large & 80 & 90.2 \\
\hline
\end{tabular}

\section{Analysis and Discussion}

Many respondents agreed that ethics are part and parcel of Confucian values; learning and continuous learning are both vital values for the self-development of individuals and organizations; individuals should self-discipline and self-cultivate themselves. They should practise good values so that their organizations can benefit from their good teamwork and team spirit to deliver the organizational goals and objectives. Some commented that good leaders are important because they are the fountainheads of the organisations; and they must set examples; leaders must embrace and practice good values (ethics) that would influence their corporate cultures; leaders must have high integrity (no self-interest or personal gain); and they should encourage team spirit in their organizations and care about the society at large.

Note that one of the key findings is that humanism and human assets are strongly emphasized in Confucianism 
and based on these findings and linking these to the Asian historical perspective, the key implications for labour can thus be analyzed as follows:

\section{1) People (labour) are assets and talents to the leaders/managers and the organizations concerned}

Confucius said, "Set an example for others to follow, be lenient to people who make minor mistakes and promote talented people" (Analects of Confucius, XIII: 2) and he further remarked, "People will obey you if you promote the righteous men and suppress the evil men. And they will disobey you if you do the contrary." (Analects of Confucius, 2:19). One must surely agree with Confucius that the righteous men will do good deeds for other people and the evil men would do things for their own personal gains. The followers look at the leaders for guidance and advice; their actions speak louder than words. Successful businesses depend on excellent talent management. Indeed, talent or human capital is the primary driver of any successful company, better talents in organisations will significantly differentiate higher performance companies from the rest (Low and Ang 2012: 100; Low, 2010a). In this respect, organisations should encourage and provide facilities for employees to learn and upgrade themselves. Very truly, learning prevents one from being narrow-minded. In the Confucian sense, a small person with education is of use to the organisation/nation; of what use is a tall man who knows nothing? This shows how important education is to an individual and to the society at large. Another Chinese proverb has it that, "a bachelor of arts discusses books, a pork butcher talks of pigs." In essence, what is stressed here is the fact that a successful individual must not only continue to learn, but needs to widen his or her horizons. Indeed an individual should not shackle or chain up him(her)self to any single idea. There is a need to always try to see things with fresh eyes. If one can do this, one will be able to achieve progress and growth. To widen knowledge and open new horizons, an individual should learn from others (Low, 2010) and embark on a continuous learning journey (Low, 2012). And a mind growth stance must be adopted (Low, 2012).

Toyota, a successful Japanese business organisation, adopted the philosophy of Kaizen. Every Toyota employee from the managing team, the grassroots level, the part timers and even its contractors, they all share the same philosophy of Kaizen (改善, Hanyu Pinyin: găi shàn), i.e. "daily or continuous improvement”. This philosophy is very much similar to the Confucian ethics of thrift, perseverance as well as learning and continuous learning (學習和不㫁學習, xué xí hé bù duàn xué xỉ). Some researcher/scholars have compared and concluded that "the most important cultural traits underlying Kaizen's success in Japan lies in a pair of values deeply rooted in the Confucian ethics: thrift and perseverance" (Asayehgn, 2011).

Learning is one of the cornerstones of Confucian beliefs and values. In this research, ninety interviewees or 97.8 percent of the total number of interviewees expressed that the values of learning and continuous learning are critical for an individual as well as an organisation and some said that, "Everyone wants to learn and to improve themselves" and "I don't want just doing the same job for many years; I want to improve and upgrade myself with new skills all the times if possible"

\section{2) Good leaders/managers must take care of the people side of things. They care for their people and show concern for them}

During Confucius times, on one occasion, the stables accidentally burned down, Confucius was worried about the safety of the people and enquired if any person had been hurt but he did not ask about the horses. Confucius cared most about people. He recognized the free will of every individual, believing that if the commander of three armies had done something wrong, he could be removed, but the will of even a common person could not be taken away (Low and Ang 2012: 100; Low, 2010a). Furthermore, leaders are the fountain heads and they must set example (Low, 2009; 2002). Leaders' examples matter. Leaders must take care of their employees. Their followers follow and emulate leaders; and they are motivated by such role modelling.

In this respect, the business should take care of its employees or labour, providing stable employment, giving fair pay, ensuring employees' safety and bringing about proper treatment of the employees by their peers and fellow employees. Here, satisfying employees, the key issues in modern businesses include diversity, equal opportunity and the prevention of sexual harassment (Madura, 2007 cited in Low and Ang 2012).

\section{3) Labour or employees should be empowered}

Gone are the days where labour is strongly controlled and monitored; theory $\mathrm{X}$ becomes obsolete, and theory $\mathrm{Y}$ is to be practised (McGregor, 1960); labour or employees should be empowered.

Learning and continuous learning are both important values for an individual as well as an organisation. For Confucius, "A gentleman who studies is unlikely to be inflexible" (Analects of Confucius, I: 8; Lau, 1979: 60 cited in Low, 2012a). Very truly, being flexible in one's mind and thinking, an individual will be lively and bright; of course, learning is both good and helpful; it helps one (even organization or nation) to change and grow (Low 
2012a). The benefit of continuous learning for an individual is that one can proactively investigates new perspectives, attitudes, and behaviours, and takes steps to evaluate and improve one's performance. Obviously, learning prevents one from being narrow-minded and some employees said, "If you are educated, you can think better and you can solve problem easily"; and there was one who said, "even though I am good in this job, I am still learning because I follow the Chinese saying, “活 到 老, 學 到 老' (Hanyu Pinyin: huó dào lăo xué dào lăo, meaning as one matures, one continues to learn without stopping.") (90 interviewees or 97.8 per cent of the total interviewees responded on continuous learning).

One must admit that in these modern days, people are getting more and more knowledgeable; and in particular, labour is indeed better-educated than the labour before. The days of good information flow and internet is very rife, information and data are now easily available and accessible by all including employees. Disliking control and wanting to have a freehand, employees or labour should be given more empowerment, a greater freedom and autonomy in managing themselves. In essence, "the history of company success is the history of staff empowerment, involvement and ownership." (Low, 2002, 2000: 77).

\section{4) Familial type of relationships should be promoted}

The relationship between the leaders/managers and the employees or labour should be based upon familial type of relationships where teamwork is encouraged and promoted. A family style of management which is very people orientated is practised. Father leadership ways as aligned with Chinese or Confucian values are encouraged; the father (to clarify, this is better referred to as parental leadership) is both firm and caring; Parental leadership often shows much care and concern to the staff, and the relationships between the employer/ manager and staff are mutually satisfying (Low, 2006a). The employer acts like a parent looking after the staff's welfare, caring for them while the employees are obligated to the employer. With the leader's care and concern for the employees, and the employees' care and concern among themselves, "all-in-the-family" feelings emerge. Any conflicts should be and is settled in a harmonious way. A common Chinese saying, “和氣生財” (hé qì shēng cái) meaning "harmonious decision would produce rewards or profits" is often used or referred to when advising or settling a family or a group in dispute or disagreement. Team spirit is also bolstered, and that can be motivating to the employees, more so, when trust is gradually engendered. In this study, some interviewees remarked, "We value teamwork and ensure good team spirit amongst ourselves"; "we stay united and help each other toward success" and "we work as a family because many hands make work easy" ( 88 interviewees or 95.7 per cent of the total interviewees responded on good team work and team spirits).

\section{5) Bad leadership has its dire consequences}

Bad leadership will lead to bad governance, poor business conduct and practices which may be harmful to business reputation and promotion; and in fact may lead to losses. And should the company closed shop, the employees or labour would suffer. It is very important that leaders and managers should closely monitor employees' decisions to ensure that they are made in the best interests of the owners and the people at large including labour and that corruption is avoided and obliterated. Employees' compensations and benefits may be awarded directly tied to the corporation's performance. The corporation's financial reporting should also be accurate and transparent; it should give complete financial statements, those that are more understandable and more readily interpreted. Corporations need to fulfil their responsibility to their creditors by providing good financial reporting. As what has happened in the Enron case whereby leaders and managers conspired with the auditors and concealing some debts that the company had incurred, Enron was able to more easily borrow funds and ultimately, it went bankrupt because it could not cover the payments on all of its loans. Specifically, Enron did not disclose some of its debts and indeed, its creditors would have been concerned about extending more credits if they had fully understood how much debt Enron already had. In this respect, good governance run by a team of good and reliable people would help and improve the society in a socially responsible way (Low and Ang, 2012). For leaders and managers who embrace good business practices (in line with corporate social responsibility), they will help their companies to grow and prosper; and their employees or labour will benefit or gain from stable employment with constant income.

In sum, the importance of leaders/ managers embracing and practising Confucian ethics which have great impact on good governance and corporate social responsibility is illustrated in Figure 2. 


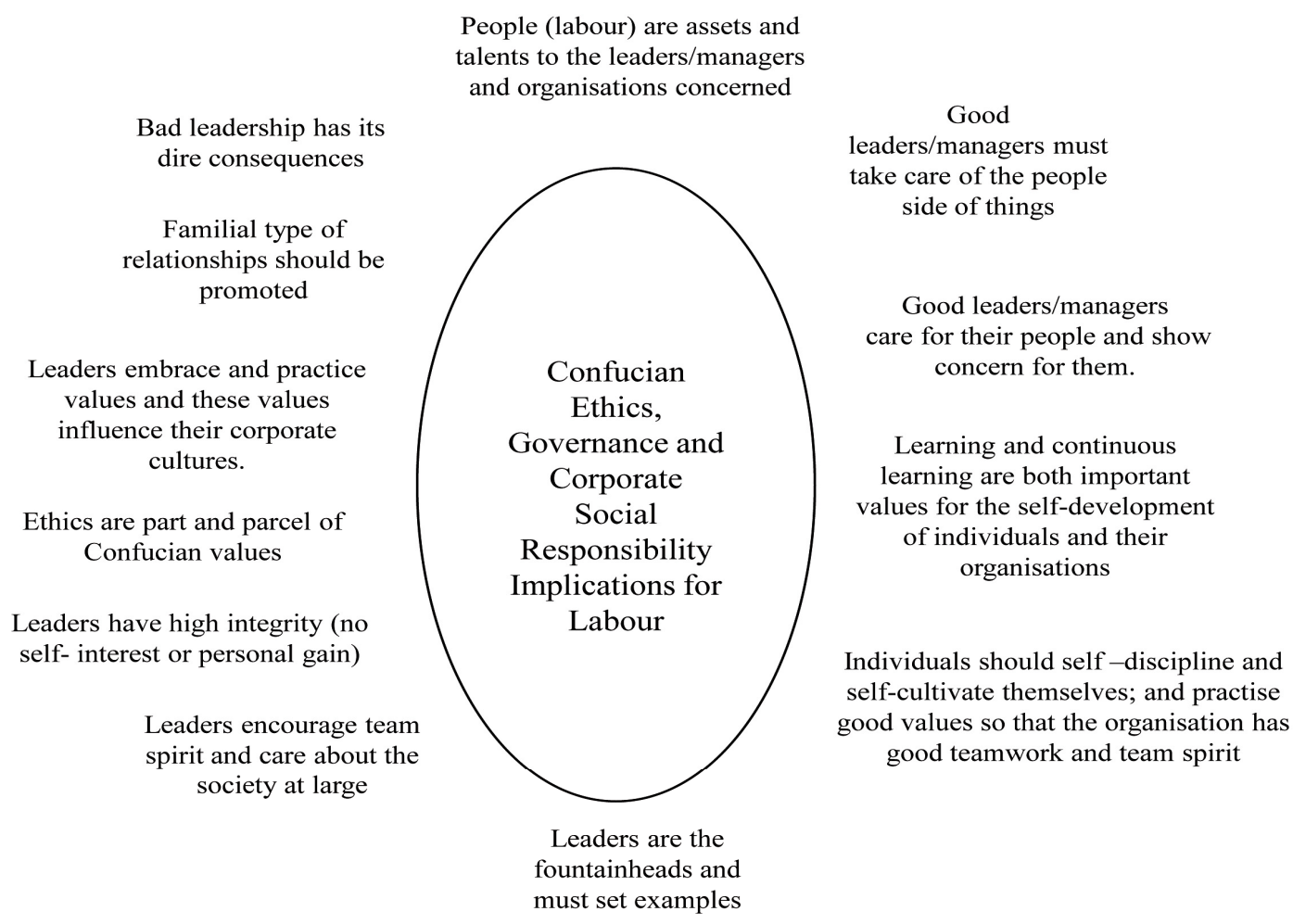

Figure 2. Confucian ethics, governance and corporate social responsibility: implication for labor

\section{Limitations \& Benefits of the Study}

It should be noted that the study was not sponsored or financed by any organisation; hence, additional interviews or focus group studies were not made. The authors feel that the key limitations of this research are the time and the cost constraints; the sample of ninety-two (92) people may limit the depth of analysis; certainly if time and costs permits, the researchers would certainly like to expand the sampling size to further enrich the data and analysis. Perhaps, a follow-up study can and should be made by other researchers; hence, this study may serve as a starting point for other Chinese Confucian ethics, governance and CSR studies in Brunei and in nearby Indonesia where there are pockets of Chinese (business) communities or in other South-east Asian countries too.

This study has, more or less, demonstrated that similar to the other Overseas Chinese in South East Asia, Chinese Bruneians are also influenced by Confucian values.

\section{Conclusion}

The key lessons learnt from this research is that weak leadership ultimately leads to poor ethical practices and poor corporate governance while strong or effective leadership can lead to good ethical practices and governance. The typical or traditional thinking that Confucian ethics is passive should be replaced with a more proactive leadership style and ways, linking Confucian ethics with the stakeholder theory. Another key message here is that leaders should indeed maintain a high integrity (a key Confucian value) and that they must live well, in line or aligned with spiritual goodness (i.e. in alignment with the Tao) to be able to lead well. And it cannot be denied that in fact, social obligation and CSR are part and parcel of the Confucian leadership and its core values system. Confucian leadership is closely tied in with the overall well-being of humanity, nature and the environment. The authors also note that CSR, when translated into Confucian terms and values, is thus focused since it specifically upholds humanity, humanism and man's relationships with nature and the environment - in line with the over-arching, superordinate Tao.

Confucius said, "Benevolence is more vital to the common people than water and fire. I have seen people die in water and fire, but I have never seen anyone die of practicing benevolence." (Analects of Confucius, XIV: 35). What Confucius meant is that by practising loving-kindness towards each other, one can attain peace and harmony in a society. From Confucian leadership thus come the stress on social obligations, ethical 
decision-making, positive business dealings and harmonious relationships and the value of learning, self-cultivation and education; and indeed these bring benefits and good practices including good business management and corporate social responsibility. Businesses must function in partnership or in a teamwork fashion with the community including being socially responsible.

Confucian ethics promotes and stresses on positive business dealings and harmonious relationships as well as the value of learning and education; and these bring many benefits and good practices including good business management and corporate social responsibility. The understandings and practices of Confucian ethics in a business organization coupled with the awareness, theory and applications of the corporate social responsibility can indeed bring much labour peace and societal harmony, learning and economic growth for an organization as well as community/ national well-being of the region.

\section{References}

Ang, S. L., \& Low, K. C. P. (2012). The Chinese and Their Motivation-The Brunei Case Study. Journal of Research in International Business Management, 2(2), 039-050.

Asayehgn, D. (2011). The Globalization of the Japanese Management Process: Reinvigorating Ethiopia's Industries through "Kaizen”. Retrieved from http://www.tigraionline.com/articles/article110414.html

Backover, M. I. (2010). Confucianism and Ethics in the Western Philosophical Tradition I: Foundational Concepts. Philosophy Compass, 5(4), 307-316. http://dx.doi.org/10.1111/j.1747-9991.2010.00295.x

Baker, M. (2004). Corporate social responsibility - What does it mean? Retrieved from http://www.mallenbaker.net/csr/definition.php

BBC. (2012). HSBC used by 'drug kingpins', says US Senate. Retrieved from http://www.bbc.co.uk/news/business-18867054

Cavana, R. Y., Delahaye, B. L., \& Sekaran U. (2001). Applied business research, qualitative and quantitative methods (pp. 142; 134-135). Australia: John Wiley and Sons.

Chai, S. C., Lai, P., \& Sia, Y. H. (1994). Analects of Confucius. Sinolingua, Beijng, China.

Chew K. H. P. (2000). A gentleman's code. Graham Brash (Pte) Ltd, Singapore.

De Bary, W. T., Chan, W. T., \& Watson, B. (1960). The sources of Chinese tradition. Columbia University Press.

Gilbert, M. (2008). A Theory of Political Obligation: Membership, Commitment and the Bonds of Society. OUP. (Paperback, 2008)

Kothari, V. B. (2010). Executive Greed. New York, USA: Palgrave Macmillan. http://dx.doi.org/10.1057/9780230109650

Lien, Y. C., \& Kraar, L. (1994). From Chinese villager to Singapore tycoon: My life story. Singapore: Times Publishing International.

Low K. C. P. (2011b). Confucianism Versus Taoism. Conflict Resolution \& Negotiation Journal, 2011(4), 111-127.

Low K. C. P. (2011b). Confucius, the Value of Benevolence and What's In It For Humanity? Conflict Resolution \& Negotiation Journal, 2011(1), 32-43.

Low, K. C. P. (2002). Corporate Culture and Values: Perception of corporate leaders of co-operatives in Singapore. Ph.D. Thesis, the University of South Australia, Adelaide.

Low, K. C. P. (2002, 2000). Strategic Customer Management. Singapore: BusinesscrAFT ${ }^{\mathrm{TM}}$ Consultancy.

Low, K. C. P. (2006a). Father leadership - The Singapore case study. Management Decision, 44(2), 89-104. http://dx.doi.org/10.1108/00251740610641481

Low, K. C. P. (2006b). Motivation, the Chinese Leadership Way In Singapore's Small and Medium Companies. The Icfaian journal of organizational behavior, V(1), 80-90. The Institute of Chartered Financial Analyst India: ICFAI University Press.

Low, K. C. P. (2008a). Value Based Leadership: Leading the Confucian way. Leadership and Organisation Management Journal, 2008(3), 32-41.

Low, K. C. P. (2008b). Confucian Ethics \& Social Responsibility - The Golden Rule and Responsibility to the Stakeholders. Ethics \& Critical Thinking Journal, 2008(4), 46-54.

Low, K. C. P. (2009a). Leading globally - What makes a successful global leader in today's turbulent times. 
e-Leader Estonia Conference, CASA: Chinese American Scholars Association, Tallinn, Estonia.

Low, K. C. P. (2009b). Confucian Ethics and Social Responsibility - The Golden Rule \& Responsibility to the Stakeholders (February 15, 2009). Ethics and Critical Thinking Journal, 4, 46-54.

Low, K. C. P. (2009c). How to lead in today's context? What leadership skills set do we need? Leadership \& organizational management Journal, 2009(1), 48-56.

Low, K. C. P. (2010a). Talent Management, the Confucian Way. Leadership \& Organizational Management Journal, 2010(3), 28-37.

Low, K. C. P. (2010b). Zen and Leadership - Growing One's Leadership Excellence. Insights to A Changing World, 2010(1), 1-10.

Low, K. C. P. (2011). Confucius, the Value of Benevolence And What's In It For Humanity? Conflict Resolution \& Negotiation Journal, 2011(1), 32 - 43.

Low, K. C. P. (2012). Confucius, Learning And Mind Growth - Want to Be A Winner? Global Education Journal, 2012(2), 118-134.

Low, K. C. P., \& Ang, S. L. (2011a). Confucian Ethics And the Stakeholder Theory In Business. i-manager's Journal on Management, 5(4), 8-20.

Low, K. C. P., \& Ang, S. L. (2011b). Confucius, Confucian Values and their Applications on Marketing-The Brunei Perspective. Journal of Research in International Business Management, 1(9), 293-303.

Low, K. C. P., \& Ang, S. L. (2012a). The Value of Integrity, The Confucian Perspective. i-manager's Journal on Management, 6(4).

Low, K. C. P., \& Ang, S. L. (2012b). The Theory and Practice of Confucian Value of Integrity. International Journal of Business and Management (IJBM), 7(14), 114-124. http://dx.doi.org/10.5539/ijbm.v7n14p114

Low, K. C. P., \& Ang, S. L. (2012c). Confucian Leadership and Corporate Social Responsibility (CSR), the Way Forward. Asian Journal of Business Research (AJBR), 2(1), 85-108.

Madura, J. (2007). Introduction to business (4th ed.). Canada: Thomson South-Western.

McGregor, D. (1960). The Human Side of Enterprise. New York: McGrawHill.

Metcalf, F., \& Gallagher, B. J. (2012). Being Buddha at Work (pp. 120-121). Inc. San Francisco, USA: Berret-Koehler Publisher.

Meyer, J. W., \& Jepperson, R. L. (2000). The "Actors" of Modern Society: The Cultural Construction of Social Agency. Sociological Theory, 18(1), 100. http://dx.doi.org/10.1111/0735-2751.00090

Mill, J. S. (1863). Utilitarianism. Retrieved from http://www.utilitarianism.com/mill1.htm

Plate, T. (2010). Citizen Singapore: How to Build A Nation. Conversations with Lee Kuan Yew, Marshal Cavendish International (Asia) Private Limited, Singapore.

Plate, T. (2011). Doctor M: Operation Malaysia. Conversation with Mahathir Mohamad Marshal Cavendish International (Asia) Private Limited, Singapore.

Roscoe, J. R. (1975). Fundamental Research Statistic for the Behavioural Sciences (2nd ed.). New York: Holt, Rinehart and Winston.

Sekaran, U. (2000). Research Methods for Business. John Wiley \& Sons, Inc.

The Straits Times. (2012). 'HSBC's lax control led to money laundering: Investigation. Retrieved from http://www.straitstimes.com/BreakingNews/World/Story/STIStory_823163.html

The World Bank. (2011). What is Governance? The World Bank Group. Retrieved from http://web.worldbank.org/WBSITE/EXTERNAL/COUNTRIES/MENAEXT/EXTMNAREGTOPGOVERN ANCE/0

WBCSD. (2000). Corporate social responsibility: Meeting the expectations. The World Business Council for Sustainable Development (WBCSD). Retrieved from http://www.wbcsd.org/DocRoot/RGk80O49q8ErwmWXIwtF/CSRmeeting.pdf

WBCSD. (2002). Corporate social responsibility: The WBCSD's Journey. Retrieved from http://www.wbesd.org/DocRoot/I0NYLirijYoHBDflunP5/csr2002.pdf

Yang, H. (1993). Prospects: the Quarterly review of comparative education. UNESCO: International Bureau of 
Education, XXIII(1/2), 211-219.

Yost, P., Pylan, P., Gordon, D. C., \& Chan, K. (2012). HSBC to pay $\$ 1.9$ billion to settle money-laudering scandal. $\quad$ Retrieved http://www.salon.com/2012/12/11/hsbc_to_pay_1_9bn_to_settle_money_laundering_scandal/ from Zhou, K. (2005). A basic Confucius (1st ed.). Long River Press, China. 